\title{
The current status of endovascular treatment for acute ischaemic stroke
}

\author{
(1) कर \\ Ismail Dogu Kilic ${ }^{1}, \mathrm{MD}$; Omer Goktekin ${ }^{2 *}$, MD \\ 1. Department of Cardiology, Pamukkale University Hospitals, Denizli, Turkey; 2. Department of Cardiology, \\ Bezmialem University Hospitals, Istanbul, Turkey
}

Stroke, a growing global healthcare burden, remains one of the leading culprits of disability and death in the Western world ${ }^{1}$. Ischaemic stroke accounts for the majority of all strokes, in which rapid restoration of blood flow to salvageable tissue at risk of infarction reduces the final area of infarct and provides better outcomes. For several years, fibrinolytic treatment with tissue plasminogen activator (tPA), within four and a half hours of the onset of symptoms, has been the primary reperfusion strategy in the treatment of acute ischaemic stroke. Nonetheless, limitations of tPA therapy, including the low rates of recanalisation in large vessel ischaemic strokes, have led to the development of endovascular approaches ${ }^{2,3}$. However, robust data to support endovascular therapy for stroke were previously lacking because of the futility in randomised trials. Despite these results, researchers have remained attentive to this approach and investigated endovascular stroke treatment in a number of trials, considering some prior limitations. Subsequently, data from MR CLEAN ${ }^{4}$, EXTEND-IA ${ }^{5}$, ESCAPE 6 , REVASCAT $^{7}$, and SWIFT PRIME ${ }^{8}$ (and expected data from other forthcoming studies) have shown improved outcomes with endovascular therapy in patients with an acute ischaemic stroke due to an arterial occlusion of the anterior circulation. Careful selection of the candidates, identification of a major vessel occlusion prior to intervention with imaging studies and effective recanalisation (TICI 2b-3) that was achieved with stent retrievers in the majority of patients contributed to good clinical outcome in the trials. Moreover, these trials achieved highly efficient workflow metrics and a relatively short time to intervention. This is particularly important, because time plays an essential role in predicting the clinical outcome and efficacy of treatment in cerebral ischaemia, as demonstrated by the analysis of these recent trials ${ }^{9,10}$.
Overall, the results were impressive and treatment remained effective across a wide range of ages and initial stroke severity as well as for both patients eligible and ineligible for intravenous tPA $^{11}$. Moreover, for every 100 patients treated, 38 would have a less disabling sequel, when compared to best medical management alone, with an extra 20 achieving functional independence with endovascular treatment ${ }^{11}$. Consequently, these compelling results led to updates of the acute stroke guidelines, strongly recommending endovascular therapy after IV tPA in the treatment of acute ischaemic stroke in well-defined settings.

The favourable outcomes attained in these trials clearly mandate the establishment and reorganisation of the management of stroke services. Initial challenges likely to be faced include ensuring a timely transfer of candidates for endovascular therapy to adequate centres. This process includes many factors: increasing public awareness, improving response times of medical services, the initiation of prehospital stroke treatment, effective triage of the patients, and, finally, establishing faster in-hospital action plans ${ }^{12}$. Another significant challenge is the dispersion of well-equipped centres, capable of performing endovascular stroke interventions.

At present, many countries, including ours (Turkey), lack a sufficient number of centres which can provide a round-the-clock service for endovascular stroke treatment. Furthermore, considering the number of patients requiring endovascular treatment, insufficient procedural volume not supporting a 24/7 available team represents a major logistical challenge, particularly in areas with scattered populations ${ }^{13}$. These challenges may limit the widespread application of such a promising therapy.

Nonetheless, cardiologists have achieved a similar organisation in the context of acute myocardial infarction (AMI) over recent

*Corresponding author: Department of Cardiology, Bezmialem University Hospitals, Fatih, Istanbul, Turkey.

E-mail:ogoktekin@gmail.com 
decades. Moreover, due to the number of procedures they perform, they have become increasingly skilled at catheter-based interventions. This highlights the potential of incorporating present organisations and workforce, in an effort to extend the services of acute stroke management. On the other hand, there are still doubts over this approach, mainly due to the concerns about the lack of a formal training. However, as supporters of this approach, we are aware of the differences in the pathophysiology of AMI and ischaemic stroke, as well as in the course of the disease and the vasculature. Therefore, the involvement of interventional cardiologists, which is of the upmost importance, does not and should not divert training (although it can be shorter), nor replace stroke teams, as this is the best way to manage stroke patients. Indeed, a previous study by our group can serve as an example of this approach: we demonstrated the possibility of attaining similar outcomes in stroke interventions performed by cardiologists working in a stroke team, to those achieved by neurointerventional centres (Figure 1$)^{14}$. These results were in accordance with the results of studies by other groups ${ }^{15,16}$.

In conclusion, we are clearly entering into a new era of acute ischaemic stroke treatment, as recent trials and their meta-analysis, including the one by Ferrante et al in this current issue of EuroIntervention, strengthen the role of endovascular treatments. Article, see page 271

However, there are many questions yet to be answered, including whether we will be able to translate the results of these wellorganised and efficient trial settings to the real world. Nonetheless, the revolution of stroke management will require a large multidisciplinary workforce, in which we believe that the involvement of interventional cardiologists would be of benefit.

\section{Conflict of interest statement}

The authors have no conflicts of interest to declare.

\section{References}

1. Lozano R, Naghavi M, Foreman K, Lim S, Shibuya K, Aboyans V, et al. Global and regional mortality from 235 causes of death for 20 age groups in 1990 and 2010: a systematic analysis for the Global Burden of Disease Study 2010. Lancet. 2012;380: 2095-128.

2. Bhatia R, Hill MD, Shobha N, Menon B, Bal S, Kochar P, Watson T, Goyal M, Demchuk AM. Low rates of acute recanalization with intravenous recombinant tissue plasminogen activator in ischemic stroke: real-world experience and a call for action. Stroke. 2010;41:2254-8.

3. Yeo LL, Paliwal P, Teoh HL, Seet RC, Chan BPL, Liang S, Venketasubramanian N, Rathakrishnan R, Ahmad A, Ng KW, Loh PK, Ong JJ, Wakerley BR, Chong VF, Bathla G, Sharma VK. Timing of recanalization after intravenous thrombolysis and functional outcomes after acute ischemic stroke. JAMA Neurol. 2013;70: $353-8$.

4. Berkhemer OA, Fransen PS, Beumer D, van den Berg LA, Lingsma HF, Yoo AJ, Schonewille WJ, Vos JA, Nederkoorn PJ,

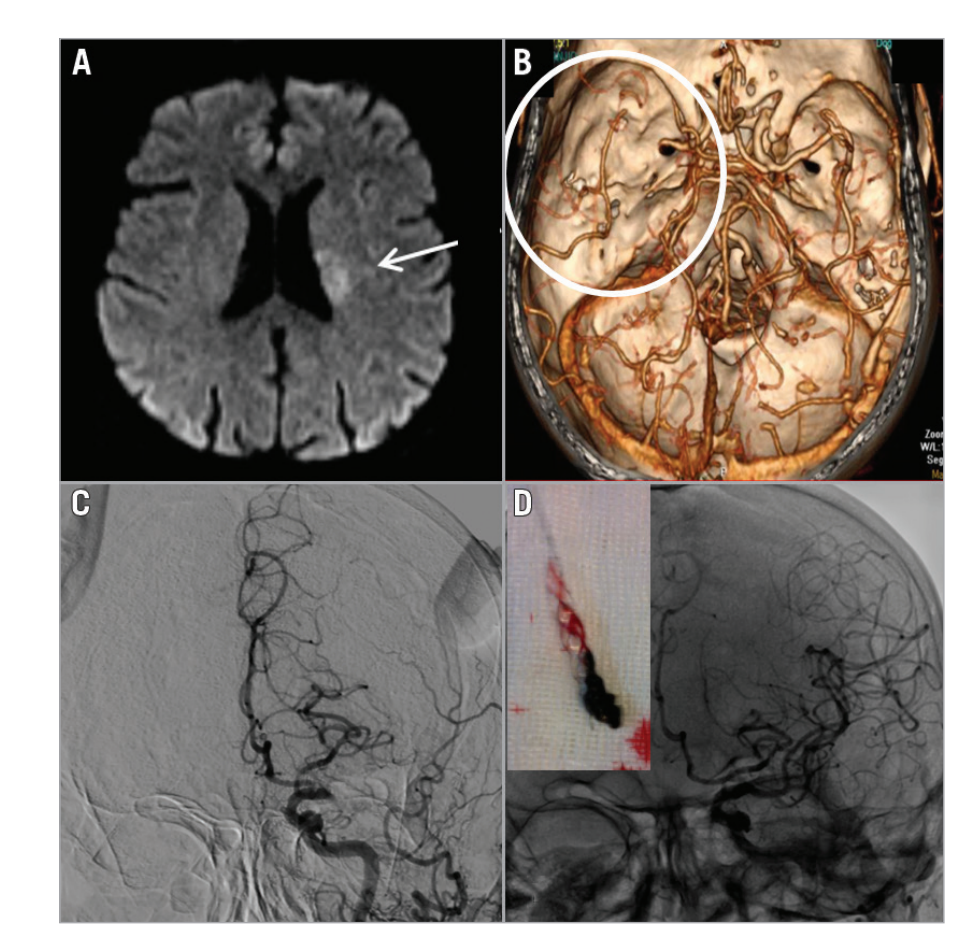

Figure 1. Case example. A 58-year-old male was admitted to hospital with right-sided weakness which had begun two hours before. Neurologic examination revealed right-sided hemiplegia, aphasia with a National Institutes of Health Stroke Scale (NIHSS) score of 20. Computed tomography with angiography showed total occlusion of the left internal carotid artery and left middle cerebral artery (A \& B). This was confirmed on cerebral angiography $(C)$. After treatment with a retrievable stent, good angiographic results were achieved (D). NIHSS score was 4 at the first hour and 2 at discharge. 
Wermer MJ, van Walderveen MA, Staals J, Hofmeijer J, van Oostayen JA, Lycklama à Nijeholt GJ, Boiten J, Brouwer PA, Emmer BJ, de Bruijn SF, van Dijk LC, Kappelle LJ, Lo RH, van Dijk EJ, de Vries J, de Kort PL, van Rooij WJ, van den Berg JS, van Hasselt BA, Aerden LA, Dallinga RJ, Visser MC, Bot JC, Vroomen PC, Eshghi O, Schreuder TH, Heijboer RJ, Keizer K, Tielbeek AV, den Hertog HM, Gerrits DG, van den Berg-Vos RM, Karas GB, Steyerberg EW, Flach HZ, Marquering HA, Sprengers ME, Jenniskens SF, Beenen LF, van den Berg R, Koudstaal PJ, van Zwam WH, Roos YB, van der Lugt A, van Oostenbrugge RJ, Majoie CB, Dippel DW; MR CLEAN Investigators. A randomized trial of intraarterial treatment for acute ischemic stroke. N Engl J Med. 2015;372:11-20.

5. Campbell BC, Mitchell PJ, Kleinig TJ, Dewey HM, Churilov L, Yassi N, Yan B, Dowling RJ, Parsons MW, Oxley TJ, Wu TY, Brooks M, Simpson MA, Miteff F, Levi CR, Krause M, Harrington TJ, Faulder KC, Steinfort BS, Priglinger M, Ang T, Scroop R, Barber PA, McGuinness B, Wijeratne T, Phan TG, Chong W, Chandra RV, Bladin CF, Badve M, Rice H, de Villiers L, Ma H, Desmond PM, Donnan GA, Davis SM; EXTEND-IA Investigators. Endovascular therapy for ischemic stroke with perfusion-imaging selection. N Engl J Med. 2015;372:1009-18.

6. Goyal M, Demchuk AM, Menon BK, Eesa M, Rempel JL, Thornton J, Roy D, Jovin TG, Willinsky RA, Sapkota BL, Dowlatshahi D, Frei DF, Kamal NR, Montanera WJ, Poppe AY, Ryckborst KJ, Silver FL, Shuaib A, Tampieri D, Williams D, Bang OY, Baxter BW, Burns PA, Choe H, Heo JH, Holmstedt CA, Jankowitz B, Kelly M, Linares G, Mandzia JL, Shankar J, Sohn SI, Swartz RH, Barber PA, Coutts SB, Smith EE, Morrish WF, Weill A, Subramaniam S, Mitha AP, Wong JH, Lowerison MW, Sajobi TT, Hill MD; ESCAPE Trial Investigators. Randomized assessment of rapid endovascular treatment of ischemic stroke. $N$ Engl J Med. 2015;372:1019-30.

7. Jovin TG, Chamorro A, Cobo E, de Miquel MA, Molina CA, Rovira A, San Román L, Serena J, Abilleira S, Ribó M, Millán M, Urra X, Cardona P, López-Cancio E, Tomasello A, Castaño C, Blasco J, Aja L, Dorado L, Quesada H, Rubiera M, HernandezPérez M, Goyal M, Demchuk AM, von Kummer R, Gallofré M, Dávalos A; REVASCAT Trial Investigators. Thrombectomy within 8 hours after symptom onset in ischemic stroke. $N$ Engl J Med. 2015;372:2296-306.

8. Saver JL, Goyal M, Bonafe A, Diener HC, Levy EI, Pereira VM, Albers GW, Cognard C, Cohen DJ, Hacke W, Jansen O, Jovin TG, Mattle HP, Nogueira RG, Siddiqui AH, Yavagal DR, Baxter BW, Devlin TG, Lopes DK, Reddy VK, du Mesnil de Rochemont R, Singer OC, Jahan R; SWIFT PRIME Investigators. Stent-retriever thrombectomy after intravenous t-PA vs. t-PA alone in stroke. N Engl J Med. 2015;372:2285-95.

9. Menon BK, Sajobi TT, Zhang Y, Rempel JL, Shuaib A, Thornton J, Williams D, Roy D, Poppe AY, Jovin TG, Sapkota B, Baxter BW, Krings T, Silver FL, Frei DF, Fanale C, Tampieri D, Teitelbaum J, Lum C, Dowlatshahi D, Eesa M, Lowerison MW,
Kamal NR, Demchuk AM, Hill MD, Goyal M. Analysis of Workflow and Time to Treatment on Thrombectomy Outcome in the ESCAPE Randomized Controlled Trial. Circulation. 2016 Apr 13. [Epub ahead of print].

10. Fransen PS, Berkhemer OA, Lingsma HF, Beumer D, van den BergLA, YooAJ, SchonewilleWJ, Vos JA, NederkoornPJ, WermerMJ, vanWalderveen MA, Staals J,HofmeijerJ, van OostayenJA, Lycklama À Nijeholt GJ, Boiten J, Brouwer PA, Emmer BJ, de Bruijn SF, van Dijk LC, Kappelle LJ, Lo RH, van Dijk EJ, de Vries J, de Kort PL, van den Berg JS, van Hasselt BA, Aerden LA, Dallinga RJ, Visser MC, Bot JC, Vroomen PC, Eshghi O, SchreuderTH, Heijboer RJ, Keizer K, Tielbeek AV, den Hertog HM, Gerrits DG, van den Berg-Vos RM, Karas GB, Steyerberg EW, Flach HZ, Marquering HA, Sprengers ME, Jenniskens SF, Beenen LF, van den Berg R, Koudstaal PJ, van Zwam WH, Roos YB, van Oostenbrugge RJ, Majoie CB, van der Lugt A, Dippel DW; Multicenter Randomized Clinical Trial of Endovascular Treatment of Acute Ischemic Stroke in the Netherlands (MR CLEAN) investigators. Time to Reperfusion and Treatment Effect for Acute Ischemic Stroke: A Randomized Clinical Trial. JAMA Neurol. 2016;73:190-6.

11. Goyal M, Menon BK, van Zwam WH, Dippel DW, Mitchell PJ, Demchuk AM, Dávalos A, Majoie CB, van der Lugt A, de Miquel MA, Donnan GA, Roos YB, Bonafe A, Jahan R, Diener HC, van den Berg LA, Levy EI, Berkhemer OA, Pereira VM, Rempel J, Millán M, Davis SM, Roy D, Thornton J, Román LS, Ribó M, Beumer D, Stouch B, Brown S, Campbell BC, van Oostenbrugge RJ, Saver JL, Hill MD, Jovin TG; HERMES collaborators. Endovascular thrombectomy after large-vessel ischaemic stroke: a meta-analysis of individual patient data from five randomised trials. Lancet. 2016;387:1723-31.

12. Tatlisumak T. Implication of the recent positive endovascular intervention trials for organizing acute stroke care: European perspective. Stroke. 2015;46:1468-73.

13. Campbell BC, Donnan GA, Lees KR, Hacke W, Khatri P, Hill MD, Goyal M, Mitchell PJ, Saver JL, Diener HC, Davis SM. Endovascular stent thrombectomy: the new standard of care for large vessel ischaemic stroke. Lancet Neurol. 2015;14:846-54.

14. Goktekin O, Tasal A, Uyarel H, Vatankulu MA, Sonmez O, Kul S, Ay N, Yamac H, Altintas O, Karadeli H, Kolukisa M, Aralasmak A, Asil T. Endovascular therapy of acute ischaemic stroke by interventional cardiologists: single-centre experience from Turkey. EuroIntervention. 2014;10:876-83.

15. Htyte N, Parto P, Ragbir S, Jaffe L, White CJ. Predictors of outcomes following catheter-based therapy for acute stroke. Catheter Cardiovasc Interv. 2015;85:1043-50.

16. Widimsky P, Asil T, Abelson M, Koznar B, Tasal A, Roos J, Vasko P, Peisker T, Deniz C, Vavrova J, Yamac HA, Stetkarova I, Bacaksiz A, Ay NK, Tuzgen S, Maly M, Goktekin O. Direct Catheter-Based Thrombectomy for Acute Ischemic Stroke: Outcomes of Consecutive Patients Treated in Interventional Cardiology Centers in Close Cooperation With Neurologists. J Am Coll Cardiol. 2015;66:487-8. 